早川 峰司

北海道大学病院先進急性期医療センター

（ ○060-8648 北海道札幌市北区北 14 条西5丁目）

\section{A confusion of the oxygen saturation}

Mineji Hayakawa

Emergency and Critical Care Center, Hokkaido University Hospital

(N14W5 Kita-ku, Sapporo, Hokkaido 060-8648, Japan)

J Jpn Soc Intensive Care Med 2016;23:181-2.

\title{
パルスオキシメータの低酸素血症検出精度
}

\section{編集委員長殿}

本誌 21 巻 2 号 $(2014$ 年 3 月号) に掲載された我々の 短報「パルスオキシメーターの低酸素血症検出に関す る信頼性の検討」1)を御覧頂き, 鈴木ら 2) が本誌 22 巻 2 号 (2015年 3 月号) に投稿したレター「集中治療患者 における至適 $\mathrm{SpO}_{2} 」$ を興味深く扯読致しました。我々 が報告した $90 \% \leqq \mathrm{SpO}_{2}<93 \%$ の患者群で $\mathrm{SpO}_{2}$ と $\mathrm{SaO}_{2}$ 值が乘離するという結果に対し, 集中治療室在室 患者を対象とした後ろ向き研究では, パルスオキシ メータの信頼性に患者の重症度が大きく影響するとの 御意見は, 本研究の限界を示す鋭い指摘と受け止めま した。

鈴木ら2)が指摘する通り, 重症度の高い患者では, アシドーシス, 高乳酸血症, 貧血など $\mathrm{SpO}_{2}$ と $\mathrm{SaO}_{2}$ の 乘離に影響を与える因子に異常值を示していることが 多く,これが $\mathrm{SpO}_{2}$ 值の信頼性を低下させることはす でに報告されています3)。このバイアスを回避するた め, 我々はカテーテル検査を予定されている慢性血栓 閉塞性肺高血圧症患者を対象とし，3種類のパルスオ キシメー夕機種を比較した前向き観察研究を行いまし た ${ }^{4)}$ 。対象患者の $\mathrm{SaO}_{2}$ は $93.1 \pm 3.5 \%$ で, 3 機種いず れも $\mathrm{SpO}_{2}$ は $\mathrm{SaO}_{2}$ より高值を示すという結果が得られ ました。

今回得られた結果は, 慢性血栓閉塞性肺高血圧症患 者を対象としており，集中治療室入室患者に必ずしも 当てはまるとは限りません。しかし, 我々が 3 種類の パルスオキシメータより得られたデー夕を統計学的に
解析した結果では, 低酸素血症を避けるための閾値は 89 92\%と，機種ごとに大きく異なりました4)。

パルスオキシメータは多数の企業が営利目的で開発 競争している装置であり, $\mathrm{SpO}_{2}$ は各社ごとに秘匿さ れた別々のアルゴリズムに基づき算出される数字であ ることは厳然たる事実です。顧客の要求に応えるため, 多くの機能を盛り込もうと開発競争した結果, 低酸素 領域での $\mathrm{SpO}_{2}$ 值が機種ごとにばらつくのは当然の帰 結かもしれません。

Suzuki らは前後比較研究において 5 ), $\mathrm{SpO}_{2}$ の目標範 囲を90〜 92\%に設定した「酸素制限療法」が, 酸素投 与制限をしていない従来療法と比較して, 有害事象を 発生させず安全に施行できたことを報告しました。今 後「酸素制限療法」が広く臨床応用される可能性を踏 まえ, 低酸素血症の判断においては装置ごとの検証が 必要であることは, 集中治療医として胸に留めておく 必要のある事実と考え, 報告させて頂きます。

本稿のすべての著者には規定されたCOIはない。

\section{文 献}

1) 金井理一郎, 鵜澤康二, 森山 潔, 他. パルスオキシメー ターの低酸素血症検出に関する信頼性の検討。日集中医誌 2014;21:175-6.

2) 鈴木 聡, 森松博史. 集中治療患者における至適 $\mathrm{SpO}_{2}$. 日 集中医誌 2015;22:156-7.

3) Wilson BJ, Cowan HJ, Lord JA, et al. The accuracy of 
pulse oximetry in emergency department patients with severe sepsis and septic shock: a retrospective cohort study. BMC Emerg Med 2010;10:9.

4) Kohyama T, Moriyama K, Kanai R, et al. Accuracy of pulse oximeters in detecting hypoxemia in patients with chronic thromboembolic pulmonary hypertension. PLoS One 2015;10:e126979.

5) Suzuki S, Eastwood GM, Glassford NJ, et al. Conservative oxygen therapy in mechanically ventilated patients: a pilot before-and-after trial. Crit Care Med 2014;42:1414-22.

受付日 2015 年 6 月 15 日 採択日 2015 年 7 月 21 日
森山潔, 金井理一郎, 萬

知子

杏林大学医学部麻酔科学教室

（干 181-8611＼cjkstart東京都三鷹市新川 6-20-2）

\section{Accuracy of pulse oximeters in detecting hypoxemia}

Kiyoshi Moriyama, Riichiro Kanai, Tomoko Yorozu

Department of Anesthesiology, Kyorin University School of Medicine (6-20-2 Shinkawa, Mitaka, Tokyo 181-8611, Japan)

J Jpn Soc Intensive Care Med 2016;23:182-3.

\section{メトヘモグロビン血症で動脈血酸素飽和度は低下しない}

\section{編集委員長殿}

橋本らの論文1)とこれに対する「今号のハイライ ト」2)を興味深く拝読いたしました。

混乱を避けるため本レターでは以下のように定義す る。

oxygen saturation $\left(\mathrm{sO}_{2}\right)=\mathrm{cO}_{2} \mathrm{Hb} /\left(\mathrm{cO}_{2} \mathrm{Hb}+\mathrm{cHHb}\right)$ fractional oxyhemoglobin $\left(\mathrm{FO}_{2} \mathrm{Hb}\right)=\mathrm{cO}_{2} \mathrm{Hb} / \mathrm{ctHb}$ ここでctHb $=\mathrm{cO}_{2} \mathrm{Hb}+\mathrm{cHHb}+\mathrm{cCOHb}+\mathrm{cMetHb}$ なお, c: concentration, F: fruction, tHb: total hemoglobin, $\mathrm{O}_{2} \mathrm{Hb}$ : oxyhemoglobin, $\mathrm{HHb}$ : deoxyhemoglobin, COHb: carboxyhemoglobin, MetHb: methemoglobin である。 本報告は次の 2 点で興味深い。

1点目は初めから $\mathrm{FO}_{2} \mathrm{Hb}$ に着目したことである。メ トへモグロビン血症では $\mathrm{SpO}_{2}$ と $\mathrm{sO}_{2}$ の数值に乘離が 生じる。通常, メトへモグロビン血症では, 「 $\mathrm{SpO}_{2}$ が 低值を示し, 動脈血をCO-oximetryにより調べると $\mathrm{PaO}_{2}, \mathrm{sO}_{2}$ が正常であることから, 酸素化能に問題が ないことが確認され, $\mathrm{SpO}_{2}$ 測定に影響しその值を低 下させる物質の存在を疑い, 分画をみると FMetHbが 上昇していることに気がついた」という報告が多い。 本報告においては, 逆に $\mathrm{SpO}_{2}$ が高く $\mathrm{FO}_{2} \mathrm{Hb}$ が低いこ とを発端として, 異常へモグロビンの存在を疑い, そ
の分画をみるとFMetHbが上昇していることが判明 している。

メトへモグロビンの増加は, $\mathrm{SpO}_{2}, \mathrm{FO}_{2} \mathrm{Hb}$ どちら の数值も低下させる。Pulse oximetryでは660 nmの 赤色光 $\mathrm{R}$ と $940 \mathrm{~nm}$ の赤外光IRの 2 波長の吸光度の比 から $\mathrm{SpO}_{2}$ を測定している。 I/IR=1.0では $\mathrm{SpO}_{2}=$ $85 \%$ であるため, この 2 波長でほほ同じ吸光度を示す メトへモグロビンが増加すると $\mathrm{SpO}_{2}$ は低下し $85 \%$ に 近づく。一方, tHbが一定でメトへモグロビンが増加 すれば $\mathrm{FO}_{2} \mathrm{Hb}$ は低下する。このため $\mathrm{SpO}_{2}, \mathrm{FO}_{2} \mathrm{Hb}$ ど ちらもその数值は低下するが臨床的には $\mathrm{FO}_{2} \mathrm{Hb}$ の方 がより低值を示すことになる。

本報告の場合, $\mathrm{FO}_{2} \mathrm{Hb}$ 87.1\%, FMetHb 9.2\%であ れば, $\mathrm{sO}_{2}$ は100〜 96\%であるので, $\mathrm{SpO}_{2}$ が $96 \%$ なら, この条件ではメトへモグロビンによる $\mathrm{SpO}_{2}$ の低下は ほとんどないことになる。橋本らの報告において術後, 明らかにメトへモグロビンによる $\mathrm{SpO}_{2}$ の測定值の低 下が認められる。本報告にある気管挿管中の条件下で は, メトへモグロビンの影響が出にくいとも考えられ る。このときのCO-oximetryでの動脈血の $\mathrm{sO}_{2}$ がいく つであったか興味が持たれる。

2 点目は, 動脈血酸素飽和度の定義として $\mathrm{FO}_{2} \mathrm{Hb}$ を 